\title{
筋活動に着目した学生フォーミュラ車両の運転姿勢の検討
}

○伊藤 一也（一関工業高等専門学校 未来創造工学科）

岡野 滉 (JXTGエナジー (株)), 中島 萌 (SUBARUテクノ (株))

\section{A Study of Driving Position for Student Formula Vehicle Focused on Muscle Activity}

Kazuya ITOH (National Institute of Technology, Ichinoseki College,

Department of Engineering for Future Innovation),

Kou OKANO (JXTG Energy Co. Ltd.), Moyuru NAKASHIMA (SUBARU Techno Co., Ltd.)

\section{1.はじめに}

1981年にアメリカ自動車技術協会 (SAE) が開催 したFormula SAEは，日本でも2003年から (公社) 自動車技術会の主催で毎年9月に本大会が開催さ れる.フォーミュラ車両の設計はFormula SAE統 一ルールの下で行われている。 フォーミュラ車両 の運転姿勢は市販乗用車と異なり，ドライバーの 踵のフロア接地位置(ヒールポイント)がヒップポ イントより上側にある. 岩手連合学生フォーミュ ラチームの2017年参戦車両では, ヒールポイント がヒップポイントより約 $45 \mathrm{~mm}$ 上方にあり (図1), フォーミュラ車両設計の参考書を含め, 多くの学 生フォーミュラチームで同様の運転姿勢になる車 両設計が見られる1). これより，学生フォーミュ ラ車両固有の運転姿勢を前提に, 疲労が少なく正 確で速い運転が可能な運転姿勢を設計することが, 学生フォーミュラ大会において良い成績をおさめ る上で重要と考えられる. 以上より, 本研究では, 運転姿勢に大きく影響すると考えられる下記 $4 つ$ のパラメータを対象に, ドライバーの平均走行タ イムと筋活動の両面から学生フォーミュラ車両の 運転姿勢を検証することを目的とした。

実験(1) シート背面角度 (座面角度 $5^{\circ}$ 固定) 実験(2) シート座面角度(背面角度 $35^{\circ}$ 固定) 実験(3) ペダル面角度 (背面 $35^{\circ} /$ 座面 $5^{\circ}$ 固定) 実験(4) JM50肩関節〜ステアリングの距離 （背面 $35^{\circ} /$ 座面 $5^{\circ}$ /面角度 $15^{\circ}$ 固定）

\section{2. 実験方法}

実験は，PlayStation3(ソフト：GranTurismo6) とハンドルコントローラ(Logicool G29)，32イン チ液晶ディスプレイ，アルミフレームによるドラ イビングモックアップから成るDS (図2)と，ワイ ヤレス筋電計(グローバル・リンクス・テクノロ ジ一製EMG-EYE)を用いて，以下のとおり実施した。

- 実験参加者 : 19〜22歳の男性9名, 女性1名
- 計測項目 :

カートコース8周の平均走行タイム

筋活動 (積分筋電の正規化)

(左右三角筋前部，左右腓腹筋 (実験(3))

- 官能評価 :

座りやすさ (実験(1)，(2))

ペダル操作のしやすさ(実験(3))

ハンドル操作のしやすさ(実験(4))

・実験パラメータ

> シート背面角度 : 20/25/30/35/40 (deg. )

> シート座面角度 : 0/5/10/15/20（deg.）

>ペダル面角度 : 0/5/10/15/20（deg.）

> 肩関節〜ステアリングの距離 : 500/525/550/575/600 (mm)

なお，実験前に実験参加者がドライビングシ ミュレータを練習し，運転操作に充分慣れた事を 確認してから実験を実施した。この時，シート座 面角度 $5^{\circ}$ ， シート背面角度 $35^{\circ}$ ，ペダル面角度 $15^{\circ}$ ，JM50体格の肩関節〜ステアリング間の距 離550mmである．また，本研究の実験は一関工業 高等専門学校の倫理審査の承認を得た後実施した.

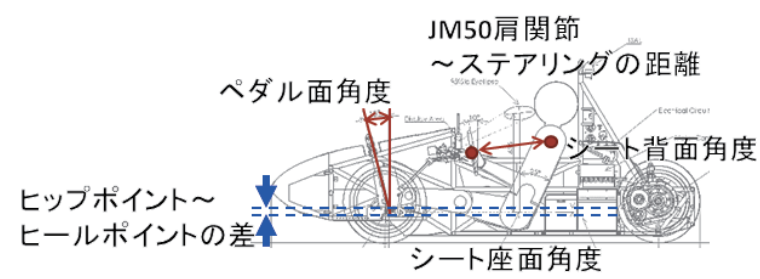

図1 学生フォーミュラ車両とパラメータ

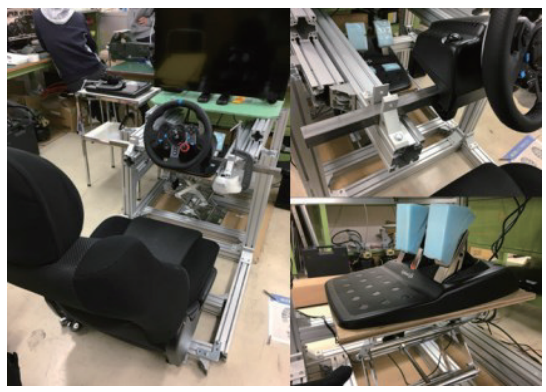

図2 ドライビングシミュレータ 


\section{3. 実験結果}

3. 1 シートの座りやすさ (実験(1), (2))

シートの背面角度および座面角度の違いによる 三角筋前部の積分筋電と座りや寸さの関係を示し た結果を, 図3，図4に示寸。これより，シート背 面角度 $30^{\circ}$ ，座面角度 $15^{\circ}$ の条件が座りやすさ と積分筋電の少なさのバランスが良い可能性があ る事が示された.

\section{2 ペダル操作のしやすさ (実験(3)}

ペダル面角度の違いによる左右腓腹筋の積分筋 電と座りやすさの関係を示した結果について，ブ レーキペダル(左足)を図5，アクセルペダル(右 足)を図6に示す。これより，左右とも $15^{\circ}$ が最 も操作しやすく, ブレーキペダルは $15^{\circ}$ が最も 筋活動が高い傾向が示された。 なお，ペダル操作 しやすさの官能評価は，全員が左右いずれのペダ ルも同じ評価で回答した.

\section{3 ハンドル操作のしやすさ (実験(4))}

ハンドル操作のしや寸さの結果，肩関節からス テアリングまでの距離が500～575mmの範囲で操作 しやすく，600mmでは操作しやすさが低下寸る傾 向が見られた。

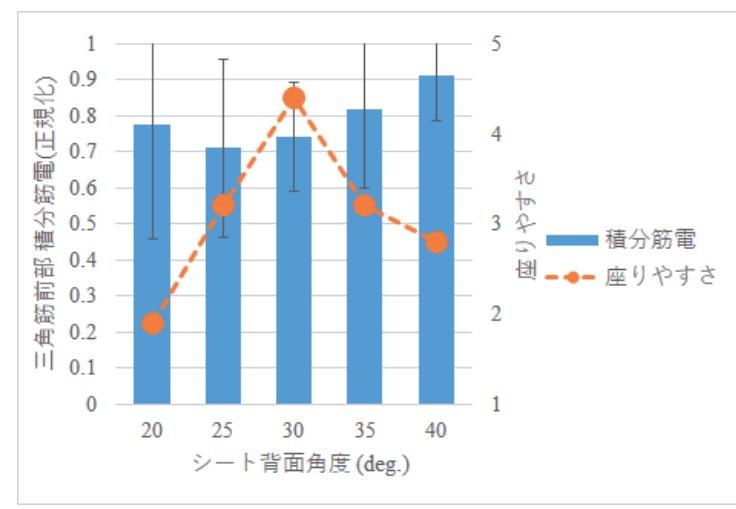

図3 シ一ト背面角度の実験結果

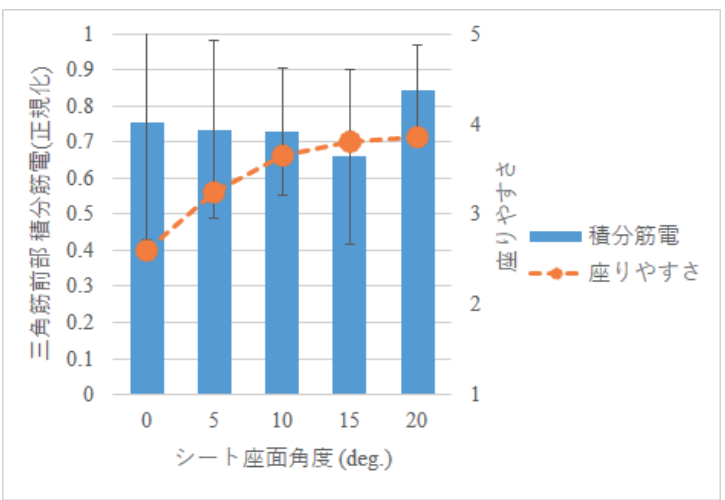

図4 シ一ト座面角度の実験結果

\section{4. 考察}

シートの座りやすさについては，踵位置がヒッ プポイントから上にある分，身体が寝た姿勢にな ることで中立姿勢2) に近づき，座りやすい姿勢と 感じやすいと考えられる. また，ペダル操作のし や寸さについては，実験参加者10名の自然な足首 角度の平均值が $15^{\circ}$ 弱であったことから，自然 な状態から踏めること，また，ブレーキペダル操 作については力を入れやすい方が良いと感じやす いものと考えられる. ステアリング操作について は，600mmでは腕が伸びて回しにくくなるものと 考えられる.

\section{参考文献}

1) DEREK SEWARD : "RACE CAR DESIGN", Palgrave, pp. 41, 2014.

2）平尾 章成他：“面的評価に基づく肉体疲労低 減運転姿勢の提案”, バイオメカニズム学会, 19 巻 pp. 125-136, 2008.

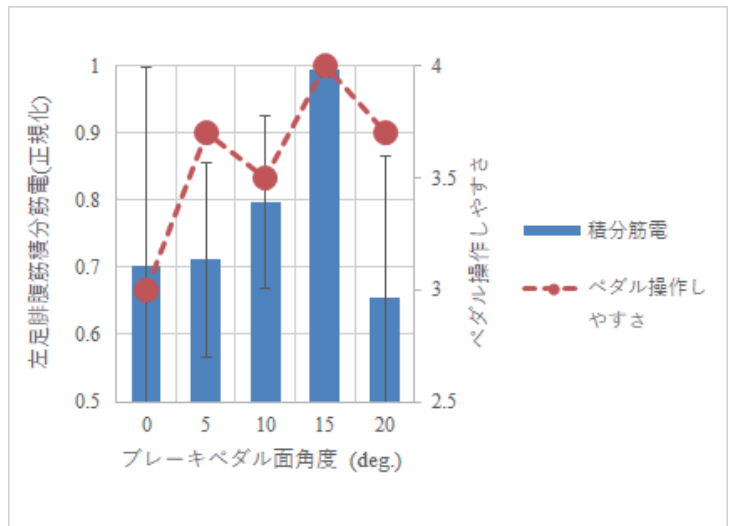

図5ブレ一キペダル面角度の実験結果

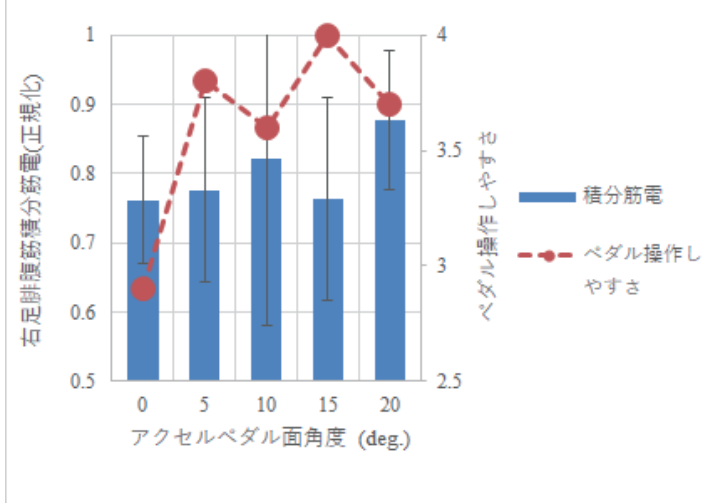

図6アクセルペダル面角度の実験結果 